NASA/TM-2002-211488

AIAA-2002-0934

\title{
Alternatives to the ISS Plasma Contacting Units
}

\author{
Dale C. Ferguson
}

Glenn Research Center, Cleveland, Ohio 
Since its founding, NASA has been dedicated to the advancement of aeronautics and space science. The NASA Scientific and Technical Information (STI) Program Office plays a key part in helping NASA maintain this important role.

The NASA STI Program Office is operated by Langley Research Center, the Lead Center for NASA's scientific and technical information. The NASA STI Program Office provides access to the NASA STI Database, the largest collection of aeronautical and space science STI in the world. The Program Office is also NASA's institutional mechanism for disseminating the results of its research and development activities. These results are published by NASA in the NASA STI Report Series, which includes the following report types:

- TECHNICAL PUBLICATION. Reports of completed research or a major significant phase of research that present the results of NASA programs and include extensive data or theoretical analysis. Includes compilations of significant scientific and technical data and information deemed to be of continuing reference value. NASA's counterpart of peerreviewed formal professional papers but has less stringent limitations on manuscript length and extent of graphic presentations.

- TECHNICAL MEMORANDUM. Scientific and technical findings that are preliminary or of specialized interest, e.g., quick release reports, working papers, and bibliographies that contain minimal annotation. Does not contain extensive analysis.

- CONTRACTOR REPORT. Scientific and technical findings by NASA-sponsored contractors and grantees.
- CONFERENCE PUBLICATION. Collected papers from scientific and technical conferences, symposia, seminars, or other meetings sponsored or cosponsored by NASA.

- SPECIAL PUBLICATION. Scientific, technical, or historical information from NASA programs, projects, and missions, often concerned with subjects having substantial public interest.

- TECHNICAL TRANSLATION. Englishlanguage translations of foreign scientific and technical material pertinent to NASA's mission.

Specialized services that complement the STI Program Office's diverse offerings include creating custom thesauri, building customized data bases, organizing and publishing research results ... even providing videos.

For more information about the NASA STI Program Office, see the following:

- Access the NASA STI Program Home Page at http://www.sti.nasa.gov

- E-mail your question via the Internet to help@sti.nasa.gov

- Fax your question to the NASA Access Help Desk at 301-621-0134

- Telephone the NASA Access Help Desk at 301-621-0390

- Write to: NASA Access Help Desk NASA Center for AeroSpace Information 7121 Standard Drive Hanover, MD 21076 


\section{Alternatives to the ISS Plasma Contacting Units}

Dale C. Ferguson

Glenn Research Center, (Ileveland, Ohio

Prepared for the

40th Aerospace Sciences Meeting and Exhibit

sponsored by the American Institute of Aeronautics and Astronautics

Reno, Nevada, January $14-17,2002$

National Aeronautics and

Space Administration

Glenn Research Center

May 2002 


\section{Available from}

NASA Center for Aerospace Information 7121 Standard Drive

Hanover, MD 21076
National Technical Information Service 5285 Port Royal Road Springfield, VA 22100

Available electronically at http://gltrs.grc.nasa.gov/GLTRS 


\title{
ALTERNATIVES TO THE ISS PLASMA CONTACTING UNITS
}

\author{
Dale C. Ferguson \\ $\mathrm{Na}$ ional Aeronautics and Space Administration \\ Glenn Research Center \\ Cleveland, Ohio 44 I 35
}

\begin{abstract}
A spacecraft in a high-density equatorial LEO plasma will float negative relative to the ambient plasma. Because of the electron collection of exposed conductors on its solar arrays, it may float negativi by up to its array voltage. The floating potential depends on the relative areas of electron and ion collection of the spacecraft. Early estimates of the International Space Station (ISS) potential were about $-140 \mathrm{~V}$ relative to the surrounding plasma, because of its $160 \mathrm{~V}$ solar array string voltage. Because of the possibility of arcing of ISS structures and astronaut EMUs (spacesuits) into the space plasma, Plasma Contacting Units (PCUs) were added to the ISS design, to reduce the highly negative floating potentials by tmitting electrons (effectively increasing the ion collecting area). In addition to the now-operating ISS PCUs, safety rules require another independent archazard control method. In this paper, I discuss alternatives to the ISS PCUs for keeping the ISS floating potential at values below the arcthresholds of ISS and EMU surface materials. Advantages and disadvantages of all of the techniques will be presenter.
\end{abstract}

\section{INTRODUC[ION}

Laboratory measurements have established that EMU suit materials may arc at potentials of $-60 \mathrm{~V}^{1.2}$. Floating Potential Probe (FPP) measurements on ISS have shown that it is possible under certain plasma conditions for parts of ISS to float at voltages this low ${ }^{3,4}$. Because of the potenially catastrophic astronaut suit arc-hazard, three independent controls must be in place. For early ISS missions, in addition to two operating PCUs, three passive potential control techniques were also used. Two of them acted to decrease solar array electron collection. The other was intended to increase the ion collection to the docked STS/ISS combination. The two array electron-collection modifying techniques were to turn the solar array conductors (on the array front sides) into the array wake and to shunt the number of active array strings. Both negatively affect the amount of power the arrays produce. The modification of ioncollection was in turning the STS/ISS combination such that the Shuttle bell nozzles are pointed into the ram. It has been estimated that the effective ram ion-collection area of the Shuttle bell nozzles is about 10 square meters.

Models of ISS floating potentials, combined with FPP measurements on orbit, have shown that ISS naturally has about 10 square meters of ion-collecting area ${ }^{5}$. Because of the surprisingly small ISS solar array electron collection, this ion-collecting area keeps the present-day ISS structure to within about $40 \mathrm{~V}$ of the plasma even in the absence of operating PCUs under most plasma conditions. FPP measurements also show that when the Space Shuttle is docked to ISS, it does not increase the effective ion-collecting area of ISS $^{9}$. This must mean that the docked Shuttle places much of the ISS ion-collecting area in its wake. Moreover, because of the new horizontal S0 truss on later mission builds, the so-called vxB charging will be increased, and 
normal plasma conditions may lead to potentials close to or equal to the present $-40 \mathrm{~V}$ safety limit. In addition, in November 2002, on mission build 12A, another solar array is scheduled to be deployed, doubling the array electron collection. Estimates of ISS charging then routinely exceed the safety limits'. Finally, during array changeouts, one of the two present PCUs will be turned off during at least one astronaut EVA, negating one of the hazard controls at a time when the amount of power available is critical. To make matters worse, FPP is no longer working, and safe ISS potentials cannot be ascertained prior to EVAs.

For all of these reasons, alternatives to PCUs for ISS potential control must be investigated, and one or more of the alternatives chosen to provide adequate astronaut EVA safety.

\section{PASSIVE TECHNIQUES}

1. The first passive technique, verified by FPP measurements, is SHUNTING all but one solar array string per panel. Because of a peculiarity of the shunting circuit, one string per panel must remain unshunted. It is the high positive voltage of one end of a solar array string relative to the other grounded end that contributes most to electron collection. Panels can be shunted independently of one another, so it is possible to shunt only one of a panel pair. However, it is either all strings (but-one) of each panel shunted or none at all.

Advantages - very effective, can be done within minutes, no cost.

Disadvantages - costs all array power, not feasible when power demands are great, unshunting leads to a minute or so of increased charging.

2. The second passive technique is TURNING THE ARRAYS INTO THEIR OWN WAKES. FPP measurements show that even if out of the ram flow by only a few degrees, array electron collection is decreased to near zero. This can also be done independently for each panel. It can be used along with or in addition to the array shunting.

Advantages - very effective, can be done within one orbit, no cost.

Disadvantages - costs about $70 \%$ of array power on the morning side of each orbit, may not be feasible when power demands are great.

3. The third passive technique is $A D D I N G$ GROUNDED ION-COLLECTING AREA. If essentially bare-metal grounded conductors can be added in sufficient amount in the ram direction, solar array electron collection may be overcome, and no charging will occur (outside of vxB charging, which is always less than $40 \mathrm{~V}$ on ISS). The amount needed is at least 10 square meters with the present ISS configuration, and will increase proportionally with added solar array area. For instance, for mission build $12 \mathrm{~A}$ and until three arrays are operational, we would need about 30 square meters in the ram direction in addition to what exists now. For instance, much of the ram side of the S0 truss could be covered with grounded conductor.

Advantages - very effective, works at all times unless ISS attitude is changed (no ops control necessary), can be used to save PCU gas for EVAs.

Disadvantages - costly, demands noncorrosive conductors, integration issues, must be increased with added arrays, may affect temperature balance.

4. The fourth passive technique is PREVENTING ARCS by ameliorating the hazardous conditions. For instance, insulating the metal parts of the EMUs can prevent arcing from astronaut EMUs. An astronaut who is not grounded to ISS structure will 
never arc. This means using insulating tethers and tools, and covering with insulating material conductors on the EMU suits where the existing insulation might be breached (neck rings and anodized aluminum parts, etc.). Arcing from ISS surfaces can be prevented by specifying thick, sealed sulfuric acid anodization on all exterior surfaces or covering them all with beta cloth, for instance.

Advantages - very effective, permanent, no ops control necessary, ubviates need for PCUs.

Disadvantages - costly, requires materials and components development program, doesn't control ISS potential for science experiments.

5. The fifth passive technicue is to GROUND THE POSITIVE END OF THE SOLAR ARRAYS. Considered by the first SSF Electrical Grounding Tiger Team and rejected as too costly, this option does prevent ISS structure charging ${ }^{6}$. With modern PMAD techniques, such as the ise of buck-boost converters, it is possible to ground the ISS solar arrays positively and use a negativeground power system without a great loss of efficiency. This system was considered for use on the now-defunct TROPIX (TRansfer Orbit Plasma Interactions eXperiment $)^{7}$.

Advantages - completely effective, permanent, no ops control necessary, obviates need for PCUs.

Disadvantages - costly, some loss of efficiency, major change 10 working system, severe integration issues.

\section{ACTIVE TECH VIQUES}

6. The first active technique is OTHER HOLLOW-CATHODE ELECTRON EMITTERS. The PCUs on ISS were sized to emit 10 amps of electrons. FPP and PCU measurements on ISS have shown that this could be reduced to 2 amps with no worries about over-current conditions ${ }^{10}$. The expelled xenon needed would be proportionally reduced. Retrofitting existing PCUs could extend their lifetime by at least a factor of five, and adding extra hollow-cathodes would provide the extra hazard controls for EVA. Other hollow-cathodes are commercially available, and are being used in other space applications, the PROSEDS electrodynamic tether experiment ${ }^{8}$, for example.

Advantages - very effective, proven by PCUs and FPP, ops already experienced in use.

Disadvantages - costly, requires periodic refueling, life issues for new designs, integration issues.

7. The second active technique is OTHER ELECTRON EMITTING DEVICES. Many such devices have been proposed. All must overcome the space charge current limitations and must prevent electron-beam instabilities, while emitting electrons beyond the ISS plasma sheath. Devices proposed for preventing charging in geosynchronous earth orbit (GEO) will not in general work for LEO because of the high current requirements (amps) and the short LEO Debye length. However, if they can be made to work, such devices typically use no working fluid except electrons.

Advantages - effective, require no refueling, relatively passive, semi-permanent.

Disadvantages - unproven in LEO, lifetime issues, integration issues, requires device development and testing program.

8. The third active technique is CHARGINGMONITORED ARRAY SHUNTING. This requires an operating monitor, such as FPP, and array shunting on demand. Software would automatically shunt one or more of the array panels when ISS charging exceeded a certain value, or when plasma conditions exist which it is predicted will lead to charging 
beyond safe values ${ }^{3,4}$. If the charging monitor operated in real-time, it could even determine through analysis of transients when arcing had occurred, and would shunt one or more arrays if it did.

Advantages - as effective as array shunting, can operate within seconds, proven by FPP.

Disadvantages - requires new or repaired FPP, requires software development, can lead to loss of power at inappropriate moments.

\section{CONCLUSION}

In order to maintain two-fault tolerance to the still real astronaut EVA shock hazard, techniques in addition to the existing ISS PCUs must be implemented. I have discussed several more-or-less viable alternatives to the existing ISS PCUs. Development and implementation of one or more alternatives is imperative for future ISS mission builds, unless the program chooses to waive its EVA safety rules.

\section{REFERENCES}

1. M.R. Carruth et al., 2001, "ISS and Space Environment Interactions Without Operating Plasma Contactor," AIAA Paper 2001-0401.

2. T. Schneider et al., 2002, "Minimum Arc Threshold Voltage Experiments on Extravehicular Mobility Unit Samples," AIAA Paper 2002-1040.

3. T. Morton and J. Minow, 2002, "Floating Potential Probe Langmuir Probe Data Reduction Results," AIAA Paper 2002-0936.

4. D.C. Ferguson and B. Gardner, 2002, "Modeling International Space Station (ISS) Floating Potentials," AIAA Paper 2002-0933.
5. D.C. Ferguson, 2001, "Charging Of The International Space Station Due To Its High Voltage Solar Arrays," Proceedings of the XVIIth Space Photovoltaic Research and Technology Conference, Ohio Aerospace Institute, Cleveland, $\mathrm{OH}$, Sept. 13, 2001, in press.

6. D.C. Ferguson, D.B. Snyder and R. Carruth, 1990, Report of the Joint Workshop of the Space Station Freedom Plasma Interactions and Effects Working Group, the Space Station Freedom Plasma Working Group, and the Space Station Freedom EMI/EMC and Electromagnetic Effects Working Group on Evaluation of Impacts of Space Station Freedom Grounding Configurations, May 2224, 1990. Final Report, Aug. 21, 1990. Available through NASA Glenn Research Center.

7. Joel L. Herr and Ricaurte Chock, 1993, "TROPIX Plasma Interactions Group Report," NASA Contractor Report 191149, NASA Lewis Research Center.

8. Vaughn et al., 2000, "Development of Polymer Coatings for the PROSEDS Tether, AIAA Paper 2000-0244.

9. D.C. Ferguson, G.B. Hillard and T.L. Morton, 2001, "The Floating Potential Probe (FPP) for ISS-Operations and Initial Results," $7^{\text {th }}$ Spacecraft Charging Technology Conference, Noordwijk, Netherlands, April 23-27.

10. B. Gardner, I. Katz, and V. Davis, 2002, "ISS Plasma Contactor Emission Currents: flight Data and Model Comparison," AIAA Paper 2002-1041. 
Public reporting burden for this collection of informatior is estimated to average 1 hour per response, including the time for reviewing instructions, searching existing data sources, gathering and maintaining the data needed, and compl:sting and reviewing the collection of intormation. Send comments regarding this burden estimate or any other aspect of this Davis Highway, Suite 1204, Arlington, VA 22202-4302 and to the Office of Management and Budget, Paperwork Reduction Project (0704-0188). Washington, DC 20503.

\begin{tabular}{|l|r|r|}
\hline 1. AGENCY USE ONLY (Leave blank) & $\begin{array}{c}\text { 2. REPOAT DATE } \\
\text { May } 2002\end{array}$ & $\begin{array}{r}\text { 3. REPORT TYPE AND DATES COVERED } \\
\text { Technical Memorandum }\end{array}$
\end{tabular}

4. TITLE AND SUBTITLE

5. FUNDING NUMBERS

Alternatives to the ISS Plasma Contacting Units

6. AUTHOR(S)

WU-755-A4-05-00

Dale C. Ferguson

7. PERFORMING ORGANIZATION NAME(S I AND ADDRESS(ES)

National Aeronautics and Space sdministration

John H. Glenn Research Center at Lewis Field

Cleveland, Ohio 44135-3191

8. Performing organization REPORT NUMBER

E-13256

9. SPONSORING/MONITORING AGENCY NAME(S) AND ADDRESS(ES)

National Aeronautics and Space . idministration

Washington, DC 20546-0001

SPONSORINGMONITORING AGENCY REPORT NUMBER

NASA TM-2002-211488

AIAA-2002-0934

11. SUPPLEMENTARY NOTES

Prepared for the 40th Aerospace sciences Meeting and Exhibit sponsored by the American Institute of Aeronautics and Astronautics, Reno, Nevada, Janı iary 14-17, 2002. Responsible person, Dale C. Ferguson, organization code 5410, 216-433-2298.

12a. DISTRIBUTION/AVAILABILITY STATE MENT

12b. DISTRIBUTION CODE

Unclassified - Unlimited

Subject Category: 18

Distribution: Nonstandard

Available electronically at http://gltrs.41c.nasa.gov/GLTRS

This publication is available from the NASA Center for AeroSpace Information. 301-621-0390.

13. ABSTRACT (Maximum 200 words)

A spacecraft in a high-density eq atorial LEO plasma will float negative relative to the ambient plasma. Because of the electron collection of exposed conductors on its solar arrays, it may float negative by up to its array voltage. The floating potential depends on the relative ireas of electron and ion collection of the spacecraft. Early estimates of the International Space Station (ISS) potential werc about $-140 \mathrm{~V}$ relative to the surrounding plasma, because of its $160 \mathrm{~V}$ solar array string voltage. Because of the po: sibility of arcing of ISS structures and astronaut EMUs (spacesuits) into the space plasma, Plasma Contacting Units (PCUs) were added to the ISS design, to reduce the highly negative floating potentials by emitting electrons (effectively increasing the ion collecting area). In addition to the now-operating ISS PCUs, safety rules require another independen arc-hazard control method. In this paper, I discuss alternatives to the ISS PCUs for keeping the ISS floating potentia at values below the arc-thresholds of ISS and EMU surface materials. Advantages and disadvantages of all of the techni fues will be presented.

\begin{tabular}{|c|c|c|c|}
\hline \multirow{2}{*}{\multicolumn{3}{|c|}{ ISS; Space plasma; Plasma contartors }} & $\begin{array}{c}\text { 15. NUMBER OF PAGES } \\
10\end{array}$ \\
\hline & & & 16. PRICE CODE \\
\hline $\begin{array}{l}\text { 17. SECURITY CLASSIFICATION } \\
\text { OF REPORT } \\
\text { Unclassified }\end{array}$ & $\begin{array}{l}\text { 18. SIECURITY CLASSIFICATION } \\
\text { OF THIS PAGE } \\
\text { Unclassified }\end{array}$ & $\begin{array}{l}\text { 19. SECURITY CLASSIFICATION } \\
\text { OF ABSTRACT } \\
\text { Unclassified }\end{array}$ & 20. LIMITATION OF ABSTRACT \\
\hline NSN 7540-01-280-5500 & & & $\begin{array}{l}\text { andard Form } 298 \text { (Rev. 2-89) } \\
\text { scribed by ANSI Std. Z39-18 } \\
3-102\end{array}$ \\
\hline
\end{tabular}

